Шнирас Шарунас Альфонсович д-р пед. наук, доцент, доцент Ласаускене Иева магистрант Литовский университет спорта г. Каунас, Литовская Республика

DOI $10.21661 / r-468530$

\title{
EVALUATION OF DETERMINANT FACTORS THAT LEAD TO SUCCESSFUL COACHING
}

Аннотация: в статье говорится, что в сегодняшнем обществе успешные тренеры, ищущиче карьеру, не только способны адаптировать приобретенные знания на практике, но и быть творческими и заинтересованными в развлекательных видах спорта. Для тренеров важны не только хорошие спортивные результаты, но и успешная карьера. Поэтому эта работа направлена на выявление факторов, определяющчих успех тренерской карьеры.

Ключевые слова: тренеры, успешная карьера.

Abstract: this paper states, that in modern society in order to achieve a successful development of coach'es career it is no longer enough to only have a knowledge of how to apply theory to practise, be creative or be able to attract new athletes. In order to achieve not only good sports results, but as well to develop oneself as a professional coach and have a successful career, new ways and factors of how to do that have to be found. This paper is going to analyze what these ways and factors are, according to coaches themselves.

Keywords: coach, successful career.

Sports results are constantly growing and that puts an extra pressure on coaches. In modern society in order to achieve a successful development of coach'es career it is no longer enough to only have a knowledge of how to apply theory to practise, be creative or be able to attract new athletes. Successfull coaching also depends on ability 
to choose the right method or approach, as well as ability to notice and evaluate changes and react appropriately.

The newest studies show that successful career is based on professional's ability to achieve some specific career goals [1]. Therefore, coaches who are already successful in their field, often show very systematic, clear and rational work approaches. The majority of successful coaches have a clear future vision, as well as a mental image of their final work result. They also express a strong knowledge in sports, education standards and psychology [3]. Athletes are often very attracted by coaches' charisma, ability to motivate and maintain an interest in sports, ability to perform enjoyable training sessions, but besides all of that, the most important and inseparable aspect of success is communication. It is being said, that chances to become a successful coach increases dramatically when a coach expresses an ability to evaluate any issues that arise looking from different perspectives and thinking outside the box when trying to solve them. Ability to look at any problem from different angles creates a room for brand new ideas which is one of the greatest skills when seeking for a successful career in coaching [3; 4].

It is noticeable that there are not a lot of studies regarding successful coaching; therefore it is very important to do more research and analyze the working methods and key factors of those coaches who are already successful in their career.

In order to obtain results of the research, a semi - structured interview has been used. Semi - structured interview is a qualitative method and was picked as a best way to obtain results, because it combines pre - determined set of queations with the opportunity for a researcher to explore particular responses further. This method also ensures the validity and accuracy of data obtained, compared with other research methods. The subject of the research is a group of coaches who work in schools. We particularly were interested in their successful work experience, methods and approaches, therefore, we prepared a questionairre in advance, in order to get a better insight of the case studied. Examples of the queastions are as follows: in your opinion, what methods led you to the successful career in coaching? Based on your experience, what are the most important key factors when trying to achieve a success in coaching? 
Participants. The target group is based on a targeted selection. There were 12 coaches participating in the research, all of them were working in schools in the cities of Kaunas, Klaipeda and Taurage. Their work experience varies from 1 year to 45 years. Semi - structured interview was performed in their work setting (sport schools), after training sessions, time agreed with coaches in advance.

Results. Qualitative research method performed in order to analyze the study of methods and approaches that lead to a successful coaching career.

Results obtained during the interview discover that successful coaching career is often perceived as a nature of high scores of sport itself. The most common statements said by coaches are as follows: «successful career means having a source that would help you to achieve the best results, which, unfortunately, i do not currently have', «in my opinion, my career has developed successfully, because during the time $i$ have trained a few successful athletes who went on to the national teams or became professionals». The analysis of interview also clearly states, that most of the coaches' success is dependent on such factors as pupils' educational achievements, communication, trust and understanding between coach and pupil, happy and motivated pupils and passion for work.

During the analysis of the results, we found out that coaches name communication as the key factor for a success in coaching, quotations from the interview: «one of the most important skills is a proper communication as well as willingness to seek for set goals', «ability to communicate with pupils leads to understanding and trust between coach and pupil». The analysis of the data also shows that different type of sport coaches name different methods and factors for a successful coaching. For example, a coach of athletics names strong skills as the most important factor for success by saying: "only development of skills in the school of sports, everything else comes as secondary factors». Coach of basketball names relationship between coach and pupils as well as trust, by saying: «i love kids and $i$ do my best in finding the best type of communication with them, $i$ try to build relationships and trust». Football coach says: there are a lot of subjects necessary, for example love for pupils, honesty and passion». Besides all the named factors, coaches also agree that it is very important for a coach to 
have authority and be an example for pupils. They also agree that motivation is a key factor, by saying: «the biggest factor when seeking for success is motivation, it all depends on how long you will be able to maintain relationship between yourself, pupils, other coaches and authorities». The last, but not least aspect that coaches agree on is talent and constant development, they say: «constant self development in chosen type of sport, endless passion for what you do, and of course, a talent, all these factors combined are the key to success».

Conclusions. According to the results, the most important factors that lead to a successful career are passion and love for work and pupils, motivation and significant achievements. Strong coaches' skills, professionalism, ability to communicate, authority, ability to set a good example for pupils, trust and talent are also inseparable part of the journey to successful coaching. On top of all that, all the coaches agree - great achievements in sports and significant results are the biggest part of successful coaching career.

\section{References}

1. Koekemoer E. (2014). An explorative study on factors influencing the career success of management employees // SA Journal of Industrial Psychology. - 2014. No40 (2). - P. 1-10.

2. Kūra M. Sportinių šokių trenerio darbo su kolektyvu pagrindiniai aspektai // Tiltai. - 2008. - No1. - P. 105-121.

3. Lisinskienè A. Trenerio vaidmuo skatinant tėvų ir paauglių sąveiką sportinèje veikloje: tėvų patirtys // Sporto mokslas. - 2016. - No. 4 (86). - P. 10-19.

4. Santos S., Jones R.L. Mesquita I. Do coaches orchestrate? The working practice of elite Portuguese coaches // Research Quarterly for Exercise and Sport. 2013. - No84 (2). - P. 263-272. 